J. Japan. Soc. Hort. Sci. 55(4) : 510-515. 1987.

\title{
Localization of Lipolytic Acyl Hydrolase in Chloroplast of Stored Spinach Leaves ${ }^{1}$
}

\author{
Naoki Yamauchi ${ }^{2}$, Shuichi Iida ${ }^{3}$, Takahisa Minamide ${ }^{4}$ \\ and Takashi Iwata \\ College of Agriculture, University of Osaka Prefecture, \\ Mozu-umemachi, Sakai, Osaka 591
}

\begin{abstract}
Summary
The localization of lipolytic acyl hydrolase ( $\mathrm{LAH}$ ) in chloroplasts was studied and the change in LAH activity determined in relation to the advance of senescence in spinach leaves stored at $25^{\circ} \mathrm{C}$.

Chloroplast fractions were prepared by differential centrifugation and sucrose density gradient centrifugation. From the distribution of chlorophyll and marker enzyme activity, it was found that the LAH was contained in broken as well as intact chloroplasts, suggesting that it may be localized in the chloroplast thylakoids.

The LAH activity of spinach chloroplasts increased after 3 days of storage coinciding with the beginning of leaf yellowing, then decreased with the advance of yellowing.

It is inferred from these results that the chloroplast LAH together with lipoxygenase, degrades the chloroplast lipids with the fatty acid hydroperoxides formed being involved in chlorophyll degradation.
\end{abstract}

\section{Introduction}

It is well known that lipolytic acyl hydrolase (LAH) and lipoxygenase (LOG) are related to the formation and peroxidation of free fatty acids, respectively $(6,7,8,9,20)$. Galliard demonstrated that endogenous phospholipids and galactolipids were hydrolyzed enzymatically to produce free fatty acids and fatty acid hydroperoxides during homogenization of potato tubers, and that the enzymes involved in this reaction were identified as $\mathrm{LAH}$ and $\operatorname{LOG}(6,7)$. He also reported that the LAH degraded most of the endogenous membrane lipids such as phospholipids and glycolipids(6).

1 Recieved for publication March 7, 1986. Mechanism of chlorophyll degradation in harvested leaf vegetables. IV.

2 Present address: Himeji College of Hyogo Prefecture, Shinzaike-honcho, Himeji, Hyogo 670

3 Present address : Institute of Radiation Breeding, National Institute of Agrobiological Resource, Ohmiyacho, Ibaraki 319-22.

4 Present address : Fuculty of Living Science, Kyoto Prefectural University, Shimogamo Kyoto 606.
We have reported in previous papers that the thiobarbituric acid (TBA) value, an index of the degree of lipid peroxidation, increased with the progression of senescence of stored spinach leaves, and that the decrease of chloroplast lipids such as monogalactosyldiglyceride, digalactosyldiglyceride and phosphatidylglycerol occurred before the beginning of chlorophyll degradation $(25,26)$. It was suggested from these findings that both LAH and LOG would break down chloroplast lipids to produce free fatty acids and fatty acid hydroperoxides, respectively.

Orthoefer and Dugan found that chlorophyll a was bleached in a system which contained linoleic acid and LOG(21). Imamura and Shimizu also reported that the tissue extracts of various plants actively bleached chlorophyll in the presence of linoleic or linolenic acid, and that LOG was necessary for the process(16). In addition, Anderson et al. purified galactolipid acyl hydrolase from the chloroplasts of pole bean ( $\mathrm{Pha}-$ seolus vulgaris L.) leaves(1). Hosoda et al. also clarified the localization of LOG in chlo- 


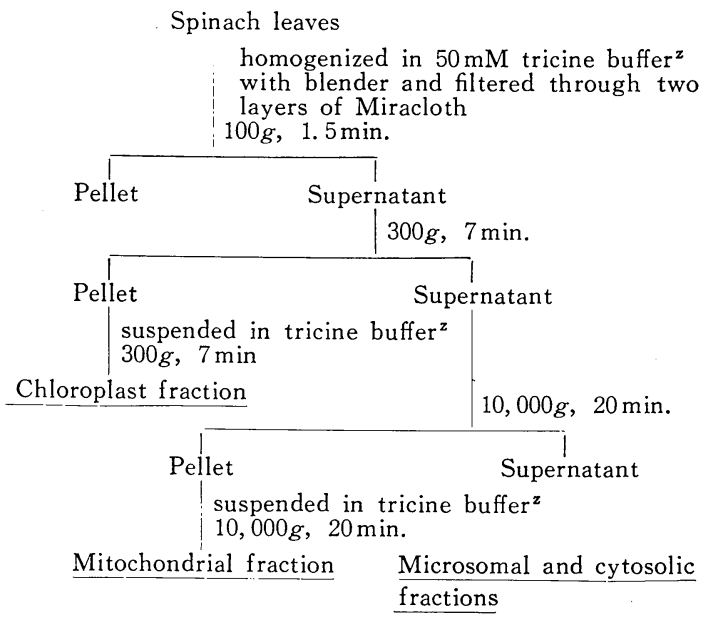

Fig. 1. Procedures used to isolate subcellular fractions in spinach leaves.

z $50 \mathrm{mM}$ Tricine, $0.5 \mathrm{M}$ sorbitol, $2 \mathrm{mM}$ EDTA, $1 \mathrm{mM}$ $\mathrm{MgCl}_{2}, 10 \mathrm{mM} \mathrm{KCl}, 1 \mathrm{mM}$ cysteine and $2.5 \% \mathrm{Ficoll}$ (pH 7.5).

roplasts of komatsuna (Brassica campestris L.) and spinach leaves(15). From these results, we postulated that the fatty acid hydroperoxides formed in the chloroplast by $\mathrm{LAH}$ and LOG would be related to chlorophyll degradation in stored spinach leaves.

The aim of the present study was to locate the LAH in spinach chloroplasts and monitor the changes in LAH activity during the senescence of stored spinach leaves. Finally the role of $\mathrm{LAH}$ in foliage senescence is discussed.

\section{Materials and Methods}

\section{Materials}

Mature leaves located from the 8 th to the 10 th from the outside of the true leaves of spinach plants (Spinacia oleracea L., cv. Atlas) were used for this study. The leaves including leafstalks were stored immediately after harvest in a closed container $\left(0.045 \mathrm{~m}^{3}\right)$ at $25^{\circ} \mathrm{C}$ under darkness with humidified air flowing at $100 \mathrm{ml}$ per min. The leaf blades without midribs were used in the following analysis.

\section{Differential gradient centrifugation}

Spinach leaves were homogenized with a blender for $10 \mathrm{sec}$ at high speed in a grinding medium $(0.5 \mathrm{M}$ sorbitol, $2.5 \%$ Ficoll, $1 \mathrm{mM}$ $\mathrm{MgCl}_{2}, 2 \mathrm{mM}$ EDTA, $10 \mathrm{mM} \mathrm{KCl}, 1 \mathrm{mM}$ cysteine and $50 \mathrm{mM}$ tricine, $\mathrm{pH} 7.5$ ). The homogenate was then centrifuged according to the procedures shown in Fig. 1.

\section{Density gradient centrifugation}

The $300 \mathrm{~g}$ pellet in Fig. 1. was resuspended in a few $\mathrm{ml}$ of the original grinding medium. A $1.5 \mathrm{ml}$ aliquot of solution was layered on the top of a linear sucrose gradient solution with $50 \mathrm{mM}$ tricine buffer (pH 7.5) containing $2.5 \%$ Ficoll, and centrifuged at $25,000 \mathrm{rpm}(80,000 \mathrm{~g})$ for $3 \mathrm{hrs}$ at $4^{\circ} \mathrm{C}$ using a Hitachi 55 P-72 ultracentrifuge. The sucrose gradient was composed of a $0.5 \mathrm{ml}$ cushion of $65 \%(\mathrm{w} / \mathrm{w})$ followed by $9 \mathrm{ml}$ of a linear gradient from $65 \%$ to $20 \%(\mathrm{w} / \mathrm{v})$. After centrifugation, each $0.5 \mathrm{ml}$ fraction was collected and enzyme activities were assayed. Homogenization and fractionation were performed at $4^{\circ} \mathrm{C}$.

\section{Enzyme assays}

The activity of NADP-triosephosphate dehydrogenase was assayed spectrophotometrically by measuring the reduction of NADP at $340 \mathrm{~nm}$ (11). Cytochrome c oxidase activity was determined by measuring the oxidation of reduced cytochrome c at $550 \mathrm{~nm}(22)$, catalase activity by measuring the reduction of hydrogen peroxide at $240 \mathrm{~nm}$ (17) and NADH-cytochrome c reductase activity by measuring the reduction of cytochrome c at $550 \mathrm{~nm}$ (13). Lipolytic acyl hydrolase was assayed by the method of Galliard and Matthew $(10)$. The reaction mixture contained $0.67 \mathrm{mM} p$-nitrophenylpalmitate, $0.135 \%$ Triton $\mathrm{X}-100,100 \mathrm{mM}$ Tris buffer $(\mathrm{pH} \mathrm{9.0)}$ and enzyme solution in a total volume of 2.0 $\mathrm{ml}$. The enzyme activity was determined spectrophotometrically by measuring the formation of $p$-nitrophenol at $400 \mathrm{~nm}$. All the enzyme activities were measured at $25^{\circ} \mathrm{C}$, with one unit being defined as a change of 0.01 in absorbance per min.

\section{Analysis of protein and chlorophyll}

Protein content was assayed by the method of Lowry et al. (18). Chlorophyll content was assayed by the method of Arnon(2).

\section{Results and Discussion}

Table 1 shows the chlorophyll content and the specific activities of marker enzymes and 
Table 1. Chlorophyll content and specific activities of marker enzymes and lipolytic acyl hydrolase in subcellular fractions prepared from spinach leaves.

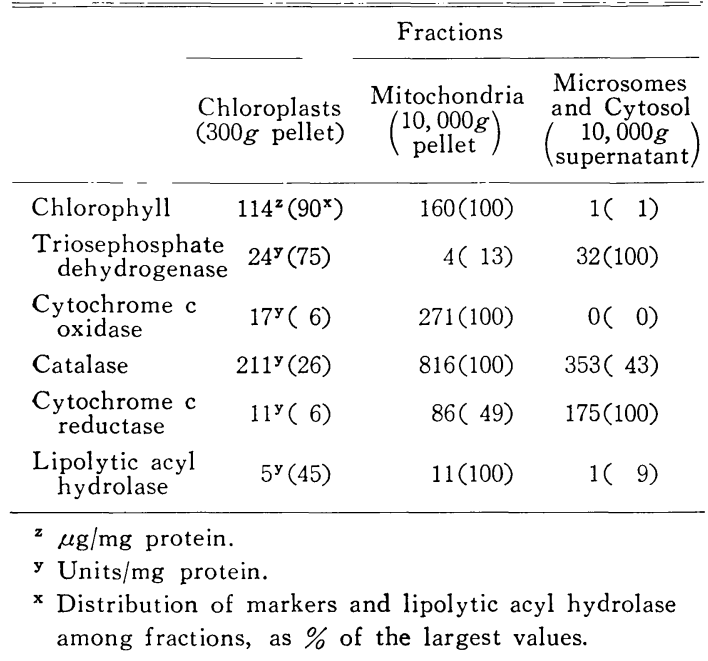

lipolytic acyl hydrolase (LAH) in subcellular fractions prepared from spinach leaves. Markers used for each of the fractions were as follows : chlorophyll content for intact and broken chloroplasts, NADP-triosephosphate dehydrogenase activity for intact chloroplasts, cytochrome $c$ oxidase activity for mitochondria, catalase activity for peroxisomes, and NADH-cytochrome $\mathrm{c}$ reductase activity for microsomes and mitochondria. As apparent in the distribution of markers, the chloroplast fraction, the pellet obtained by $300 \mathrm{~g}$ centrifugation, contained mainly intact and broken chloroplasts, but some peroxisomes were also assumed to be present. The mitochondrial fraction, the pellet obtained by $10,000 \mathrm{~g}$ centrifugation, contained not only mitochondria but also peroxisomes and broken chloroplasts. The LAH activity was found in the chloroplast and mitochondrial fractions, the highest activity shown in the latter. Some LAH activity was also found in the microsomal and cytosolic fractions.

To elucidate the distribution of $\mathrm{LAH}$ in chloroplasts, the chloroplast fraction obtained by differential centrifugation was further fractionated by sucrose density gradient centrifugation. The isolation profile of the chloroplast fraction is shown in Fig. 2. The

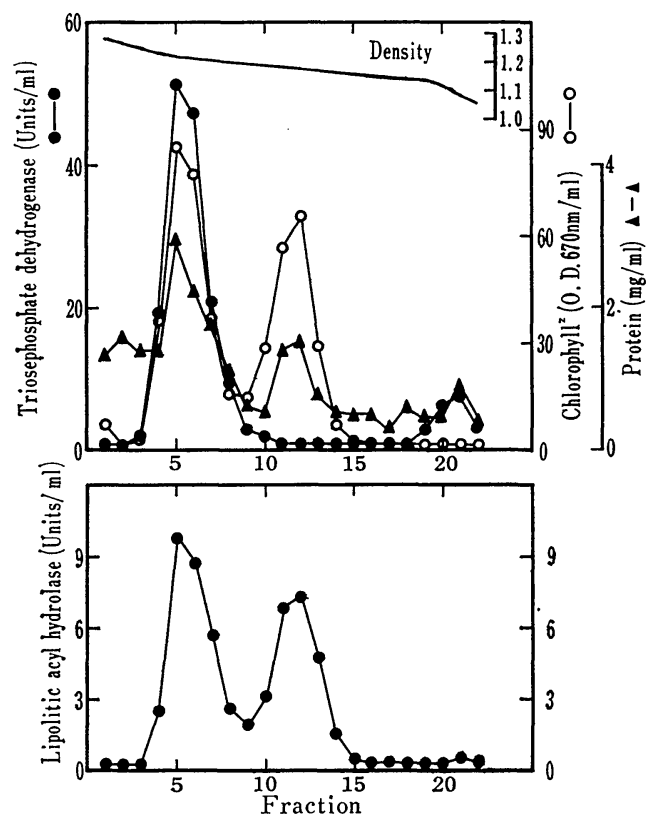

Fig. 2. Distribution of lipolytic acyl hydrolase activity after sucrose density gradient centrifugation of chloroplast fraction which was obtained by differential centrifugation.

2 Chlorophyll content was determined by adding $0.1 \mathrm{ml}$ of each fraction to $0.9 \mathrm{ml}$ of $0.5 \%$ Triton $\mathrm{X}-100$ solution and the spectral maximum of chlorophyll a in Triton X-100 solution was measured at $670 \mathrm{~nm}$.

densities of intact and broken chloroplasts were estimated to be 1.22 and 1.18 , respectively. The LAH activity was found not only in intact chloroplasts but also in broken ones since the pattern of $\mathrm{LAH}$ coincided well with that of chlorophyll content. Furthermore, comparing the LAH activity per chlorophyll of both intact and broken chloroplasts, the value was about the same, 0.12 (unit/value of O.D. $670 \mathrm{~nm}$ ) in intact chloroplasts and 0.13 in broken ones. These findings suggest that LAH activity may be localized chloroplast thylakoids.

The changes in LAH activity in chloroplasts during storage of spinach leaves at $25^{\circ} \mathrm{C}$ were studied. Spinach leaves stored at $25^{\circ} \mathrm{C}$ retained almost harvest-freshness for the first 2 days, but deteriorated rapidly after 3 days of storage showing yellowing of leaves, becoming severe after 6 days(25). As shown in Table 2, the LAH activity 
Table 2. Changes in activities of lipolytic acyl hydrolase (LAH) in chloroplasts of stored spinach leaves.

\begin{tabular}{lccc}
\hline \hline \multirow{2}{*}{$\begin{array}{c}\text { State of } \\
\text { chloroplast }\end{array}$} & \multicolumn{3}{c}{ Days in storage $\left(25^{\circ} \mathrm{C}\right)$} \\
\cline { 2 - 4 } & 0 & 3 & 6 \\
\hline Intact & $3.0^{2}\left(100^{\mathrm{y}}\right)$ & $4.5(150)$ & $2.3(77)$ \\
Broken & $4.7(100)$ & $5.9(126)$ & $4.2(89)$ \\
\hline
\end{tabular}

${ }^{2}$ Units/mg protein.

y Percent of initial activity.

The LAH activity of intact chloroplasts was determined with the collected fractions from 4 th to 8 th and that of broken ones from 10 th to 15 th shown in Fig.2.

of both intact and broken chloroplasts showed a rise after 3 days, and then declined after 6 days of storage, resulting in a lower activity than initially. In the intact chloroplasts the change in LAH activity was greater than that of the broken ones, although the reason for such a difference is not clear.

Anderson et al. reported that the galactolipase activity was localized in the chloroplasts of pole bean leaves(1). Sastry and Kates noted that the galactolipase activity of runner bean (Phaseolus multiflorus Willd.) leaves was localized in broken chloroplasts and only a low activity was found in the sedimented microsomal fraction(23). Wardale and Galliard also demonstrated that LAH activity was found in the particulate fraction $(38,000 \mathrm{~g}$ pellet) of runner bean leaves and not in the microsomal fraction(24). In this study, the LAH activity of spinach leaves was found in the chloroplast and mitochondrial fractions, but scarcely in the microsomal and cytosolic fractions. Moreover, the LAH activity was localized in the thylakoids of spinach chloroplasts in accordance with the distribution of galactolipase as shown by Sastry and Kates.

In stored spinach leaves, the LAH activity in chloroplasts increased after 3 days when the yellowing started, and then decreased after 6 days with the advance of yellowing. It has been suggested that LAH may be related to chlorophyll degradation. We reported in the previous papers that the chloroplast lipids such as monogalactosyldiglyceride, digalactosyldiglyceride and phosphatidylglycerol, decreased markedly in spinach leaves, as the TBA value increased gradually during the storage at $25^{\circ} \mathrm{C}(25,26)$. A decrease in chloroplast lipids has also been observed in stored bean leaves(5), cucumber cotyledons(4) and spinach leaves(14).

Dhindsa et al. reported that the TBA value was higher in senescent tobacco leaves than in young and mature ones(3). Maruyama et al. observed that both the TBA value and the free fatty acid content increased with yellowing of stored parsley leaves(19). From these results, it seems that LAH and lipoxygenase (LOG) are involved in the decrease in chloroplast lipids and the increase in the TBA value. The localization of LOG in chloroplasts has also been observed in alfalfa leaves(12)and in komatsuna and spinach leaves(15).

From the results obtained, together with previous evidence, the process of chlorophyll degradation may be considered as follows: LAH deacylates the chloroplast lipids to liberate unsaturated fatty acids, LOG peroxidizes these to form fatty acid hydroperoxides, and then the hydroperoxides formed cause chlorophyll degradation.

Although LAH and LOG activity are found in the chloroplasts of non-senescent spinach leaves, there is a paucity of knowledge concerning their role in non-senescent leaves.

An object for further study may be the role of LAH and LOG in the turnover of chloroplast lipids.

\section{Literature Cited}

1. Anderson, M. M., R. E. MCCARTy and E. A. ZIMMER. 1974. The role of galactolipids in spinach chloroplast lamellar membranes. I. Partial purification of a bean leaf galactolipid lipase and its action on subchloroplast particles. Plant Physiol. $53: 699-704$.

2. ARNON, D. I. 1949. Copper enzymes in chloroplasts. Polyphenol oxidase in Beta vulgaris. Plant Physiol. $24: 1-15$.

3. DHINDSA, R. S., P.P. DHINDSA and T. A. THORPE. 1981. Leaf senescence: correlated with increased levels of membrane permeability and lipid peroxidation, and decreased levels of superoxide dismutase and catalase. J. Exp. Bot. 32 : 93-101.

4. DRAPER, S. R. 1969. Lipid changes in senescing cucumber cotyledons. Phytochem. 8: 
$1641-1647$.

5. FONG, F. and R. L. HEATH. 1977. Age dependent changes in phospholipids and galactolipids in primary bean leaves (Phaseolus vulgaris). Phytochem. $16: 215-217$.

6. GALliard, T. 1970. The enzymic breakdown of lipids in potato tuber by phospholipidand galactolipid-acyl hydrolase activities and by lipoxygenase. Phytochem. $9: 1725-1734$.

7. GALliard, T. 1971. The enzymic deacylation of phospholipids and galactolipids in plants. Purification and properties of a lipolytic acyl hydrolase from potato tubers. Biochem. J. $121: 379-390$.

8. Galliard, T. 1980. Degradation of acyl lipids : hydrolytic and oxidative enzymes. p. 85-116. In : P. K. Stumpf (ed.) The biochemistry of plants. Vol.4. Lipids : structure and function. Academic Press, New York.

9. GAlliard, T. and H.W. S. Chan. 1980. Lipoxygenase. p. 131-161. In : P.K. Stumpf (ed.) The biochemistry of plants. Vol. 4. Lipids : structure and function. Academic press, New York.

10. Galliard, T. and J. A. Matthew. 1973. Lipids of potato tubers. II. Lipid-degrading enzymes in different varieties of potato tuber. J. Sci. Fd. Agric. 24 : 623-627.

11. GIBBS, M. 1955. TPN-triosephosphate dehydrogenase from plant tissue. p. $411-415$.

In : S. Colowick and N. O. Kaplan (eds.) Methods in enzymology. I. Academic press, New York.

12. Grossman, S., A. B. AZIZ, I. Ascarelli and P. BUDOWSKI. 1972. Intracellular distribution of lipoxygenase-like activity of alfalfa leaves. Phytochem. $11: 509-514$.

13. HENDRIKS, T. 1977. Multiple location of KATPase in maize coleoptiles. Plant Sci. Lett. $9: 351-363$.

14. Hirayama, O. and H. Oido. 1969. Changes of lipid and pigment compositions in spinach leaves during their storage. Nippon Nôgeikagaku Kaishi 43: 423-428. (In Japanese)

15. HosodA, K., Y. NAWA and M. KUROKI. 1980. Biochemical studies on postharvest quality changes in vegetables. Part. 8. Chlorophyll breakdown with deterioration of vegetable freshness. Rept. Natl. Food Res. Inst. 37 :
47-52. (In Japanese)

16. IMAMURA, M. and S. SHIMIZU. 1974. Metabolism of chlorophyll in higher plants. $N$. Relationship between fatty acid oxidation and chlorophyll bleaching in plant extracts. Plant Cell Physiol. 15 : 187-190.

17. KISAKI, T. 1976. Peroxisome. p. 100-108. In : Y. Morita et al. (eds.) Shokubutsukôso, tanpakushitsu kenkyûhô. (protein, nucleic acid, and enzyme, special edit) Kyôritsu shuppan, Tokyo. (In Japanese)

18. LOWRy, O. H., N. J. ROSEBROUGH, A. L. FARR and R. J. RANDALl. 1951. Protein measurement with the folin phenol reagent. J. Biol. Chem. $193: 265-275$.

19. MARUYAMA, E., M. KOBAYASHI, S. MOMOSAKI and T. KAJITA. 1976. Changes of lipid and pigment in parsley during storage. J. Home Econ. (Jpn.) $27: 428-433$. (In Japanese)

20. MinamidE, T. 1977. Lipids and physiological role of lipoxygenase in fruits and vegetables. J. Japan. Soc. Food Sci. Technol. 24 : 186199. (In Japanese)

21. ORthoefer, F. T. and L. R. DugAn, Jr. 1973. The coupled oxidation of chlorophyll a with linoleic acid catalyzed by lipoxidase. J. Sci. Fd. Agric. $24: 357-365$.

22. RochA, A. and I. P. TING. 1970. Preparation of cellular plant organelles from spinach leaves. Arch. Biochem. Biophys. 140 : 398407.

23. SASTRY, P. S. and M. KATES. 1964. Hydrolysis of monogalactosyl and digalactosyl diglycerides by specific enzymes in runner bean leaves. Biochem. 3:1280-1287.

24. WARDALE, D. A. and T. Galliard. 1975. Subcellular localization of lipoxygenase and lipolytic acyl hydrolase enzymes in plants. Phytochem. $14: 2323-2329$.

25. YAMAUChI, N., S. IIDA, T. MinAmide and T. IWATA. 1985. Foliage yellowing by peroxides in stored spinach. J. Japan. Soc. Food Sci. Technol. $32: 814-817$.

26. YAmaUCHI, N., S. IIDA, T. Minamide and T. IWATA. 1986. Polar lipids content and their fatty acid composition with reference to yellowing of stored spinach leaves. J. Japan. Soc. Hort. Sci. 55 : 355-362. 
ホウレンソウのクロロプラストにおける Lipolytic acyl hydrolase

の局在と貯蔵に伴う活性变化 ${ }^{1}$

\author{
山内直樹 ${ }^{2} \cdot$ 飯田修一 $^{3} \cdot$ 南出隆久 $^{4} \cdot$ 岩田 隆 \\ 大阪府立大学農学部 591 堺市百舌鳥梅町
}

\begin{abstract}
摘 要
ホウレンソウを材料として，脂質の加水分解に作用す る Lipolytic acyl hydrolase (LAH) のクロロプラスト での存在と, 貯蔵に伴う LAH のクロロプラスト中での 変化について検討した。

クロロプラストの分離には, 分画遠心法並びにショ糖 密度勾配遠心法を用い, 標識酵素などの分布から, LAH はクロロプラストのチラコイドに局在するものと推測し た。

ホウレンソウを $25^{\circ} \mathrm{C}$ に貯蔵すると, 貯蔵 3 日から葉 の黄化がみられ，さらに貯蔵 6 日では黄化が顕著に認め られた。貯蔵に伴うクロロプラストでの LAH 活性の変

化についてみたところ，貯蔵 3 日で活性が増大し，以後 減少して貯蔵 6 日では貯蔵当日より低い活性を示した。

以上の結果から, LAH はクロロプラストに局在し, Lipoxygenase とともにクロロプラスト脂質の分解に作 用し，生じた過酸化物がクロロフィルの分解に関与する ものと推察した。

1 収檴後における葉菜類のクロロフィル分解機構. 第 4 報.

2 現在 兵庫県立姫路短期大学

3 現在 農林水産省農業生物資源研究所放射線育種場

4 現在 京都府立大学生活科学部
\end{abstract}

